\title{
THE STATE OF DOPAMINE, SEROTONIN, ADRENAL AND GLUCOCORTICOID RECEPTORS IN CHRONIC FLUORIDE INTOXICATION
}

\author{
Irina BAGMUT ${ }^{1}$, Igor KOLISNYK ${ }^{1}$, Anna TITKOVA $^{1 凶}$, Svetlana GRAMATIUK ${ }^{1}$, \\ Anatolii GOZHENKO ${ }^{2}$
}

${ }^{1}$ Department of Clinical Pathophysiology, Topographic Anatomy and Operative Surgery, Kharkiv Medical Academy of Postgraduate Education, Kharkiv, Ukraine

${ }^{2}$ Ukraine Institute of Transport Medicine, Odesa, Ukraine

Received 5 Apr 2019, Accepted 22 May 2019

https://doi.org/10.31688/ABMU.2019.54.2.05

\section{Abstract}

The aim of the study was to assess the state of receptor binding parameters under the action of sodium fluoride on the organism under model conditions for the intoxication formation.

Material and methods. The experimental part of the work was performed on 16 white rats of the Wistar population. Internal organs and tissues were subjected to the study of the state of receptor binding parameters of labeled $\mathrm{C} 1, \mathrm{C} 2$ serotonin, $\alpha 1, \alpha 2, \beta$-adreno, D2-dopamine and glucocorticoid type II receptor agonists and antagonists in various regions of the brain and liver. The functional activity of the receptors was assessed by affinity and the number of binding sites and ligands.

Results. The study of the effect of sodium fluoride on the kinetic characteristics of the adrenoreceptors of the membrane fractions of liver cells and the cerebral cortex showed similar dynamic changes in the parameters of receptor binding of both $\alpha 1$-adreno- and $\beta 1$-adrenoreceptors. The effect of sodium fluoride was manifested in a decrease in the affinity of the radioligand for $\alpha 2$-adrenoreceptors and an increase in the number

\section{RÉsumé}

La condition des paramètres de liaison aux récepteurs de l'adrénaline, la dopamine, la sérotonine et glucocorticoïde dans les conditions de l'intoxication chronique au fluorure de sodium

Le but de la recherche était d'étudier l'état des paramètres de liaison au récepteur sous l'action du fluorure de sodium sur l'organisme dans des conditions modèles pour la formation d'une intoxication.

Materiel et méthodes. La partie expérimentale du travail a été réalisée sur 16 rats blancs de la population Wistar. Les organes et les tissus internes ont été soumis à l'étude de l'état des paramètres de liaison au récepteur des agonistes et antagonistes marqués des récepteurs $\mathrm{C} 1, \mathrm{C} 2, \alpha 1, \alpha 2$, $\beta$-adréno, D2-dopamine et glucocorticoïdes de type II, dans diverses régions du cerveau et du foie. L'activité fonctionnelle des récepteurs a été évaluée par l'affinité et le nombre de sites de liaison et de ligands.

Résultats. L'étude de l'effet du fluorure de sodium sur les caractéristiques cinétiques des récepteurs adrénergiques des fractions membranaires des cellules du 
of binding sites for this type of receptors. Similar $d y$ namics of the kinetic characteristics of $\alpha 2$-adrenoreceptors was found in the cerebellum. The number of binding sites for $\beta 1$-adrenoreceptors increased, while their affinity for ligands decreased. In the brainstem, there was a decrease in the affinity of the D2-receptors for ligands and the number of binding sites. Under conditions of subtoxic effect of sodium fluoride on white rats, a decrease in the affinity of radioligands for C2-receptors and the number of their binding sites in the cerebral cortex was observed.

Conclusions. The results of the study show that under the conditions of the formation of fluoride intoxication, structural and functional disorders of the receptor apparatus occur, which confirms the leading role in the development of this pathology of the state of biological membranes. Changes in the kinetic characteristics of adrenaline $(\alpha 1, \alpha 2, \beta 1)$, serotonin $(C 1$, $\mathrm{C} 2$ ), dopamine (D2) and glucocorticoid receptors confirm the polytropic nature of the action of sodium fluoride on organs, systems and functions of the body.

Keywords: sodium fluoride, receptors, number of binding sites, equilibrium constant dissociation.

\section{Abbreviations:}

$\mathrm{Cd}=$ equilibrium constant dissociation

$\mathrm{Bmax}=$ number of binding sites

$\mathrm{CNS}=$ central nervous system

cAMP = cyclic adenosine monophosphate foie et du cortex cérébral a montré des modifications dynamiques similaires des paramètres de liaison aux récepteurs des récepteurs adrénergiques $\alpha 1$-adrénergiques et $\beta 1$. L'effet du fluorure de sodium s'est traduit par une diminution de l'affinité du radio-ligand pour les récepteurs $\alpha 2$-adrénergiques et une augmentation du nombre de sites de liaison pour ce type de récepteurs. Une dynamique similaire des caractéristiques cinétiques des récepteurs $\alpha 2$-adrénergiques a été observée dans le cervelet. Le nombre de sites de liaison des récepteurs $\beta 1$-adrénergiques a augmenté, tandis que leur affinité pour les ligands a diminué. Dans le tronc cérébral, il y avait une diminution de l'affinité des récepteurs D2 pour les ligands et du nombre de sites de liaison. Dans des conditions d'effet sous-toxique du fluorure de sodium sur des rats blancs, une diminution de l'affinité des radio-ligands pour les récepteurs $\mathrm{C} 2$ et du nombre de leurs sites de liaison dans le cortex cérébral a été observée.

Conclusions. Les résultats de l'étude montrent que, dans les conditions de formation d'une intoxication au fluorure, des troubles structurels et fonctionnels de l'appareil récepteur se manifestent, ce qui confirme le rôle de premier plan dans le développement de cette pathologie de l'état des membranes biologiques. Les modifications des caractéristiques cinétiques des récepteurs adrénaline $(\alpha 1, \alpha 2, \beta 1)$, sérotonine $(C 1, C 2)$, dopamine (D2) et glucocorticoïdes confirment le caractère polytropique de l'action du fluorure de sodium sur les organes, les systèmes et les fonctions du corps.

Mots-clés: fluorure de sodium, récepteurs, nombre de sites de liaison, dissociation à constante d'équilibre

of competitive binding to hormones, thereby disrupting the function of the receptor apparatus ${ }^{8,9}$.

Researches of Seeman (1982) and Zhukov (1991) showed that almost all hormones probably have various ways to regulate metabolism by acting on receptors, intracellular mediation and the genome of cells, selectively suppressing or enhancing expression ${ }^{10}$. According to the generally accepted system, hormones penetrate from the bloodstream into the target cell either by free diffusion or by using special membrane systems that allow binding and transfer to the cell, where they are associated with cytoplasmic protein receptors ${ }^{11}$. The resulting hormone receptor complex is activated and acquires an increased affinity for DNA and components of the nucleus. Subsequently, the activated hormone complex is translocated into the nucleus, where it induces early effects. Our previous studies have revealed a significant effect of sodium fluoride on the structure of membranes - changes in the ratio of phospholipid fractions, stimulation of 
lipid peroxidation, a decrease in the activity of marker membrane-specific enzymes, stress function of the monooxygenase system and impaired tissue respiration and oxidative phosphorylation ${ }^{1214}$.

The OBJeCtive WAS to STUDY the state of receptor binding parameters under the action of sodium fluoride on the organism under model conditions for the intoxication formation.

\section{Materials AND Methods}

The experimental part of the work was performed on 16 white rats of the Wistar population, in the morning, on an empty stomach. For 1.5 months daily, the fasting sodium fluoride was orally administered at the rate of $20 \mathrm{mg} / \mathrm{kg}$ of body weight. At the end of the sub-acute experience, the animals were killed by decapitation. Internal organs and tissues were subjected to the study of the state of receptor binding parameters of labeled $\mathrm{C} 1, \mathrm{C} 2$ serotonin, $\alpha 1$, $\alpha 2, \beta$-adreno, D2-dopamine and glucocorticoid type II receptor agonists and antagonists in various regions of the brain and liver. The functional activity of the receptors was assessed by affinity and the number of binding sites and ligands. The method of radioligand receptor binding was used. The value of specific binding was determined by the difference between general and non-specific binding. The results were analysed in the Scatchard coordinates. Kinetic characteristics were expressed in terms of $\mathrm{Cd}$ (equilibrium constant dissociation) and Bmax (number of binding sites), taking into account the methodological recommendations of P.V. Sergeev, N.L. Shimanovsky (1987) according to generally accepted methods.

\section{Results}

The study of the effect of sodium fluoride on the kinetic characteristics of the adrenoreceptors of the membrane fractions of liver cells and the cerebral cortex showed similar dynamic changes in the parameters of receptor binding of both $\alpha 1$-adreno- and $\beta 1$-adrenoreceptors. It should be noted that the affinity of radioligands for $\alpha 1$-adrenoreceptors decreased in the cortex and the number of their binding sites increased. A different picture of the kinetic characteristics was noted when evaluating $\beta 1$-adrenoreceptors, for which the affinity for radioligands and the number of binding sites decreased. In the liver, the affinity of radioligands for $\alpha 1$-adrenoreceptors and the number of receptor binding sites decreased. The effect on $\beta 1$-adrenoreceptors was characterized by an increase in the affinity of radioligands for receptors and a decrease in the number of their binding sites (Table 1).

In the next series of experiments, the kinetic parameters of $\alpha 2$-adrenoreceptors in the brain structure the cortex, stem, cerebellum - were studied. The effect

Table 1. Effect of sodium fluoride on the kinetic characteristics of $\alpha 1, \beta 1$-adrenoreceptors of membrane fractions of liver cells and cerebral cortex in the formation of fluoride intoxication. ( $\mathrm{Cd}-\mathrm{nM}, \mathrm{Bmax}-\mathrm{pmol} / \mathrm{mg}$ protein)

\begin{tabular}{|c|c|c|c|c|c|c|c|c|}
\hline \multirow{4}{*}{$\begin{array}{l}\text { Groups } \\
\text { of animals }\end{array}$} & \multicolumn{8}{|c|}{ Objects of study } \\
\hline & \multicolumn{4}{|c|}{ Liver } & \multicolumn{4}{|c|}{ Cerebral Cortex } \\
\hline & \multicolumn{2}{|c|}{$\beta 1$-adrenoreceptors } & \multicolumn{2}{|c|}{$\alpha_{1}$-adrenoreceptors } & \multicolumn{2}{|c|}{$\beta 1$-adrenoreceptors } & \multicolumn{2}{|c|}{$\alpha_{1}$-adrenoreceptors } \\
\hline & $B_{m a}$ & $\mathrm{Cd}$ & $B_{\max }$ & $\mathrm{Cd}$ & $B_{\max }$ & $\mathrm{Cd}$ & $B_{\max }$ & $\mathrm{Cd}$ \\
\hline $\begin{array}{c}\text { Control } \\
(\mathrm{n}=7)\end{array}$ & $\begin{array}{l}0.27 \pm \\
0.003\end{array}$ & $4.30 \pm 0.18$ & $\begin{array}{c}0.78 \pm \\
0.0003\end{array}$ & $\begin{array}{c}7.60 \pm \\
0.34\end{array}$ & $\begin{array}{l}0.25 \pm \\
0.006\end{array}$ & $\begin{array}{c}1.85 \pm \\
0.21 \\
\end{array}$ & $\begin{array}{l}1.19 \pm \\
0.03\end{array}$ & $\begin{array}{c}3.40 \pm \\
0.20\end{array}$ \\
\hline $\begin{array}{l}\text { Experimental } \\
\qquad(n=9)\end{array}$ & $\begin{array}{c}0.08 \pm 0.0002 \\
P<0.05\end{array}$ & $\begin{array}{c}2.40 \pm 0.17 \\
P<0.05\end{array}$ & $\begin{array}{c}0.48 \pm \\
0.0004 \\
P<0.05\end{array}$ & $\begin{array}{c}16.4 \pm \\
0.57 \\
P<0.05\end{array}$ & $\begin{array}{l}0.12 \pm 0.003 \\
P<0.05\end{array}$ & $\begin{array}{c}21.5+ \\
0.35 \\
\mathrm{P}<0.05\end{array}$ & $\begin{array}{c}1.72 \pm \\
0,06 \\
P<0.05\end{array}$ & $\begin{array}{c}13.8 \pm 0.46 \\
P<0.05\end{array}$ \\
\hline
\end{tabular}

Table 2. The effect of sodium fluoride on the kinetic characteristics of the binding of $3 \mathrm{H}$-rauvolsin in brain structures under the conditions of the formation of fluoride intoxication. (Cd- nM, Bmax - pmol/mg protein)

\begin{tabular}{|c|c|c|c|c|c|c|}
\hline \multirow{4}{*}{$\begin{array}{c}\text { Groups } \\
\text { of animals }\end{array}$} & \multicolumn{6}{|c|}{ Objects of study } \\
\hline & \multicolumn{2}{|c|}{ Cerebellum } & \multicolumn{2}{|c|}{ Trunk } & \multicolumn{2}{|c|}{ Brain cortex } \\
\hline & \multicolumn{2}{|c|}{$\alpha_{2}-$ adrenoreceptors } & \multicolumn{2}{|c|}{$\alpha_{2}$-adrenoreceptors } & \multicolumn{2}{|c|}{$\alpha_{2}-$ adrenoreceptors } \\
\hline & $B_{m a x}$ & $\mathrm{Cd}$ & $B_{\max }$ & $\mathrm{Cd}$ & $B_{\max }$ & $\mathrm{Cd}$ \\
\hline Control & $19.6 \pm$ & $0.82 \pm$ & $21.4 \pm$ & $0.52 \pm$ & $25.4 \pm$ & $0.33 \pm$ \\
\hline$(n=7)$ & 0.40 & 0.004 & 0.43 & 0.03 & $0-9$ & 0.002 \\
\hline Experimental $(n=9)$ & $27.5 \pm 0.60$ & $0.54 \pm$ & $32.6 \pm$ & $0.46 \pm$ & $42.6 \pm$ & $0.80 \pm$ \\
\hline$(n=9)$ & $\mathrm{P}<0.05$ & $\begin{array}{c}0.003 \\
P<0.05\end{array}$ & $\begin{array}{c}1.15 \\
P<0.05\end{array}$ & $\begin{array}{c}0.002 \\
P<0.05\end{array}$ & $\begin{array}{c}2.3 \\
P<0.05\end{array}$ & $\begin{array}{l}0.0003 \\
P<0.05\end{array}$ \\
\hline
\end{tabular}


of sodium fluoride was manifested in a decrease in the affinity of the radioligand for $\alpha 2$-adrenoreceptors and an increase in the number of binding sites for this type of receptors. Similar dynamics of the kinetic characteristics of $\alpha 2$-adrenoreceptors was found in the cerebellum (Table 2). Analyzing the kinetic parameters of receptor binding in the medulla oblongata $\alpha 1$-adreno-, $\alpha 2$-adreno- and $\beta 1$-adrenoreceptors, the increase in the affinity of radio-ligands for $\alpha 1$-adrenergic receptors and a decrease in the number of binding sites for this type of receptors was established. In all cases, $\alpha 2$-adrenoreceptor activity increased - the affinity of the number of radioligand binding sites increased.

As follows from the results shown in Table 3, the number of binding sites for $\beta 1$-adrenoreceptors increased, while their affinity for ligands decreased. Determination of receptor binding parameters of dopamine receptors was carried out in the cerebral cortex, stem, and cerebellum. According to existing concepts, this type of receptor is divided into two types: D1 associated with adenylate cyclase and D2 - not associated with adenylate cyclase or involved in its inactivation ${ }^{15-16}$. Neuroleptics used in endocrine, neurological and psychiatric disorders are known to modify the activity of the D2-dopamine receptors. According to many authors, most of the toxic effects of dopamine agonists are mediated by D2 receptors ${ }^{17-19}$.
$3 \mathrm{H}$-spiperone was used as a labeled ligand, which has a high affinity for D2-dopamine receptors. The results of the experiments revealed a change in the kinetic parameters of the functional activity of this type of receptors, which consisted in a change in the affinity of radioligands and the number of their receptor binding sites. The directionality of these processes in different parts of the brain was ambiguous. An increase in receptor affinity for ligands and a decrease in the number of binding sites were observed in the cerebral cortex and cerebellum. In the brainstem, there was a decrease in the affinity of the D2-receptors for ligands and the number of binding sites (Table 4).

The established dissociation constants and kinetic characteristics of serotonin receptors of the first $\mathrm{C} 1$ and second $\mathrm{C} 2$ types showed a change in their functional activity in the cortex, stem, and cerebellum of the brain. The action of sodium fluoride was accompanied by an increase in the affinity of the ligand for C2-receptors in the cortex, stem, and a decrease in the cerebellum. The number of binding sites increased in the brainstem (Table 5). Under conditions of subtoxic effect of sodium fluoride on white rats, a decrease in the affinity of radioligands for $\mathrm{C} 2$-receptors and the number of their binding sites in the cerebral cortex was observed (Table 6).

Table 3. The effect of sodium fluoride on the adrenoreceptors kinetic characteristics of the medulla oblongata in conditions of the formation of fluoride intoxication. ( $\mathrm{Cd}-\mathrm{nM}, \mathrm{Bmax}-\mathrm{pmol} / \mathrm{mg}$ protein)

\begin{tabular}{|c|c|c|c|c|c|c|}
\hline \multirow{3}{*}{$\begin{array}{l}\text { Groups } \\
\text { of animals }\end{array}$} & \multicolumn{6}{|c|}{ Objects of study } \\
\hline & \multicolumn{2}{|c|}{$\begin{array}{l}\text { medulla oblongata, } \\
\alpha_{1}-\text { adrenoreceptors }\end{array}$} & \multicolumn{2}{|c|}{$\begin{array}{l}\text { medulla oblongata, } \\
\alpha_{2} \text {-adrenoreceptors }\end{array}$} & \multicolumn{2}{|c|}{$\begin{array}{l}\text { medulla oblongata } \\
\beta_{1} \text {-adrenoreceptors }\end{array}$} \\
\hline & $B_{\max }$ & $\mathrm{Cd}$ & $B_{\max }$ & $\mathrm{Cd}$ & $B_{\max }$ & $\mathrm{Cd}$ \\
\hline Control & $1.50 \pm$ & $8,2 \pm$ & $0,05 \pm$ & $7,2 \pm$ & $0,58 \pm$ & $1,25 \pm$ \\
\hline \multirow[t]{3}{*}{$(n=7)$} & 0,16 & 0,14 & 0,0002 & 0,09 & 0,0002 & 0,015 \\
\hline & $0,75 \pm 0,06$ & $5,10 \pm$ & $0,12 \pm$ & $4,60 \pm$ & $0,804 \pm$ & $3,10 \pm$ \\
\hline & $\mathrm{P}<0,05$ & 0,22 & 0,003 & 0,07 & 0,0003 & 0,06 \\
\hline $\begin{array}{l}\text { Experimental } \\
\quad(n=9)\end{array}$ & & $\mathrm{P}<0.05$ & $\mathrm{P}<0,05$ & $\mathrm{P}<0,05$ & $\mathrm{P}<0,05$ & $\mathrm{P}<0,05$ \\
\hline
\end{tabular}

Table 4. The effect of sodium fluoride on the binding parameters of 3H-spiperon by D2-dopamine receptors. $(\mathrm{Cd}-\mathrm{nM}, \mathrm{Bmax}-\mathrm{pmol} / \mathrm{mg}$ protein).

\begin{tabular}{ccccccc}
\hline \multirow{2}{*}{$\begin{array}{c}\text { Groups } \\
\text { of animals }\end{array}$} & \multicolumn{7}{c}{ Objects of study } \\
\cline { 2 - 7 } & $\mathrm{B}_{\max }$ & $\mathrm{C}$ Cortex, & \multicolumn{2}{c}{$\begin{array}{c}\text { Trunk, } \\
\text { D2-receptoptors }\end{array}$} & \multicolumn{2}{c}{$\begin{array}{c}\text { Cerebellum, } \\
\text { D2-receptors }\end{array}$} \\
\cline { 2 - 7 } & $92.5 \pm$ & $0.38 \pm$ & $49.3 \pm$ & $0.21 \pm$ & $81.4 \pm$ & $\mathrm{Cd}$ \\
\hline Control & 2.6 & 0.004 & 1.7 & 0.015 & 1.50 & $0.41 \pm$ \\
\hline$(\mathrm{n}=7)$ & $69.5 \pm$ & $0.17 \pm$ & $42.4 \pm$ & $0.34 \pm$ & $64.2 \pm$ & $0.25 \pm$ \\
\hline Experimental $(\mathrm{n}=9)$ & 2.6 & 0.002 & 1.16 & 0.0007 & 2.17 & 0.003 \\
\hline & $\mathrm{P}<0.05$ & $\mathrm{P}<0.05$ & $\mathrm{P}<0.05$ & $\mathrm{P}<0.05$ & $\mathrm{P}<0.05$ & $\mathrm{P}<0.05$ \\
\hline
\end{tabular}


It is well known that an important place in the regulation of metabolic processes and maintaining homeostasis belongs to glucocorticoid receptors and their sensors ${ }^{20-21}$. When studying the state of type II glucocorticoid receptors, we used glucocorticoid dexamethasone, which, as is well known, does not interact with other types of glucocorticoid cytoplasmic receptors and transcortin. The results of radioligand binding of glucocorticoid receptors in the liver, cortex, stem, and cerebellum showed a similar direction, which was characterized by an increase in the number of this type of receptors in all organs (Table 7).

\section{Discussion}

Analysis of the kinetic parameters of receptor binding shows that the affinity of radioligands for $\alpha 1$-adrenoreceptors and the number of sites of their binding decreases in the liver, the identical dynamics of the kinetic characteristics of $\beta 1$-adrenoreceptors was observed in the cerebral cortex. These data indicate that sodium fluoride has an antagonistic effect on the function of the receptor unit of hepatocytes and nerve cells. In the cerebral cortex, receptor affinity for ligands decreased and the number of $\alpha 1$-adrenoreceptor binding sites increased, whereas receptor binding dynamics in the liver had a different direction, that is, the affinity of radioligands for receptors increased and the number of binding sites decreased.

According to modern concepts, the common property of $\alpha 2$-adrenoreceptors is the induction of cAMP reduction through inhibition of adenylate cyclase $^{22}$. Stimulation of $\alpha 2$-adrenoreceptors may be accompanied by an increase in vagal influence, a decrease in the activity of the peripheral nervous

Table 5. The effect of sodium fluoride on the binding parameters of $3 \mathrm{H}$-serotonin receptors of the first type $(\mathrm{Cl})$ in brain structures $(\mathrm{Cd}-\mathrm{nM}, \mathrm{Bmax}-\mathrm{pmol} / \mathrm{mg}$ protein).

\begin{tabular}{|c|c|c|c|c|c|c|}
\hline \multirow{3}{*}{$\begin{array}{c}\text { Groups } \\
\text { of animals }\end{array}$} & \multicolumn{6}{|c|}{ Objects of study } \\
\hline & \multicolumn{2}{|c|}{$\begin{array}{c}\text { Cortex } \\
\text { C }_{1} \text {-receptors }\end{array}$} & \multicolumn{2}{|c|}{$\begin{array}{c}\text { Trunk, } \\
\text { Ci-receptors }^{-}\end{array}$} & \multicolumn{2}{|c|}{$\begin{array}{l}\text { Cerebellum, } \\
\mathrm{C}_{1} \text {-receptors }\end{array}$} \\
\hline & $B_{\max }$ & $\mathrm{Cd}$ & $B_{\max }$ & $\mathrm{Cd}$ & $B_{\max }$ & $\mathrm{Cd}$ \\
\hline Control & $302.4 \pm$ & $1.44 \pm$ & $385.4 \pm$ & $1.70 \pm$ & $225.6 \pm$ & $1.03 \pm$ \\
\hline$(n=7)$ & 6.7 & 0.03 & 7.2 & 0.06 & 3.8 & 0.03 \\
\hline \multirow[t]{3}{*}{ Experimental $(n=9)$} & $365.8 \pm$ & $1.16 \pm$ & $310.7 \pm$ & $1.30 \pm$ & $265.8 \pm$ & $1.35 \pm$ \\
\hline & 6.9 & 0.006 & 5.8 & 0.04 & 4.9 & 0.06 \\
\hline & $P<0.05$ & $P<0.05$ & $P<0.05$ & $\mathrm{P}<0.05$ & $P<0.05$ & $P<0.05$ \\
\hline
\end{tabular}

Table 6. The effect of sodium fluoride on the binding parameters of $3 \mathrm{H}$-spiperon receptors of the second type $(\mathrm{C} 2)$ in brain structures $(\mathrm{Cd}-\mathrm{nM}, \mathrm{Bmax}-\mathrm{pmol} / \mathrm{mg}$ protein).

\begin{tabular}{|c|c|c|c|c|}
\hline \multirow{3}{*}{$\begin{array}{l}\text { Groups } \\
\text { of animals }\end{array}$} & \multicolumn{4}{|c|}{ Objects of study } \\
\hline & \multicolumn{2}{|c|}{$\begin{array}{c}\text { Cortex } \\
\text { C }_{2} \text {-receptors }\end{array}$} & \multicolumn{2}{|c|}{$\begin{array}{c}\text { Trunk, } \\
\text { C }_{2} \text {-receptors }\end{array}$} \\
\hline & $B_{m o}$ & $\mathrm{Cd}$ & $B_{m a}$ & $\mathrm{Cd}$ \\
\hline Control $(\mathrm{n}=7)$ & $\begin{array}{c}33.5 \pm \\
0.57\end{array}$ & $\begin{array}{l}0.36 \pm \\
0.006\end{array}$ & $\begin{array}{c}36.8 \pm \\
0.43\end{array}$ & $\begin{array}{l}0.29 \pm \\
0.003\end{array}$ \\
\hline Experimental $(n=9)$ & $\begin{array}{c}25.3 \pm 0.45 \\
P<0.05\end{array}$ & $\begin{array}{c}0.20 \pm 0.0015 \\
P<0.05\end{array}$ & $\begin{array}{c}26.5 \pm 0.42 \\
P<0.05\end{array}$ & $\begin{array}{c}0.14 \pm 0.002 \\
P<0.05\end{array}$ \\
\hline
\end{tabular}

Table 7. The effect of sodium fluoride on glucocorticoid receptor type II ( $\mathrm{rmol} / \mathrm{mg}$ protein).

\begin{tabular}{ccc}
\hline Organs, used indicator & \multicolumn{2}{c}{ Group of animals, $\mathrm{M} \pm m$} \\
\cline { 2 - 3 } $\begin{array}{c}\text { Liver, } \\
\text { glucocorticoid receptors type II }\end{array}$ & Control $(n=7)$ & Experimental $(n=9)$ \\
\hline Cerebellum, glucocorticoid receptors type II & $520.4+10.3$ & $\begin{array}{c}710.5+9.2 \\
\mathrm{P}<0.05\end{array}$ \\
\hline Brain stem, glucocorticoid receptors type II & $615.7+16.5$ & $\begin{array}{c}930.8+12.4 \\
\mathrm{P}<0.05\end{array}$ \\
\hline Cerebral cortex, glucocorticoid \\
receptors type II
\end{tabular}


system, arterial pressure, a violation of the secretory function of the gastrointestinal tract, etc. ${ }^{23-25}$

Of the known adrenergic mechanisms of the CNS one can suppose that in the cells of various brain regions due to the detected changes the following should be observed: disturbances on the part of phospholipid fractions, in particular, phosphatidylinositol, a decrease in the level of intracellular cAMP and a decrease in adenylate cyclase activity, which testify to a deep reorganization of cellular metabolism ${ }^{26-28}$.

The violation of the structural and functional state of dopamine D2-receptors as a result of a change in their dissociation constant and the number of binding sites should be expected to lead to the difficulty of neurotransmitter information transfer to intracellular structures and the realization of its function by dopamine ${ }^{29}$.

The observed increase in the number of glucocorticoid receptors is probably associated with a powerful manifestation of the effect of nuclear translocation of this type of receptors in combination with steroids $^{30}$. It is possible that the prolonged effect of sodium fluoride on the change in the homeostatic level of the glucocorticoid hypothalamic-pituitary-adrenal system in animals leads to the involvement of type II glucocorticoid receptors and the genetic apparatus of the cell in the structurally metabolic process, which probably increases the body's resistance to harmful factors. The different level of type II glucocorticoid receptors in the animal studied tissues is determined, apparently, by the severity of their cellular metabolism.

\section{Conclusions}

Thus, the results of the study show that under the conditions of the formation of fluoride intoxication, structural and functional disorders of the receptor apparatus occur, which confirms the leading role in the development of this pathology of the state of biological membranes. Changes in the kinetic characteristics of adrenaline $(\alpha 1, \alpha 2, \beta 1)$, serotonin (C1, C2), dopamine (D2) and glucocorticoid receptors confirm the polytropic nature of the action of sodium fluoride on organs, systems and functions of the body.

Acknowledgements. We thank all the members of the research team.

\section{Compliance with Ethics Requirements:} this article"
„The authors declare that all the procedures and experiments of this study respect the ethical standards in the Helsinki Declaration of 1975, as revised in 2008(5), as well as the national law."

„All institutional and national guidelines for the care and use of laboratory animals were followed"

„No funding for this study"

\section{References}

1. Shashi A, Meenakshi G. Inhibitory effect of fluoride on $\mathrm{Na-K}$ ATPase activity in human erythrocyte membrane. Biol Trace Elem Res. 2015;168(2):340-348.

2. Akimov OYe, Kostenko VO. Functioning of nitric oxide cycle in gastric mucosa of rats under excessive combined intake of sodium nitrate and fluoride. J Ukr Biochem. 2016;88 (6):70-75.

3. Yadav N, Sharma S, Sharma K, et al. Protective role of diet supplements Spirulina and Tamarind fruit pulp on kidney in sodium fluoride exposed Swiss albino mice: histological and biochemical indices. Indian J Exp Biol. 2016;54(1):44-55.

4. Arnold WH, Haase A, Hacklaender J, et al. Effect of $\mathrm{pH}$ of amine fluoride containing toothpastes on enamel remineralization in vitro. BMC Oral Health. 2007;17:7-14.

5. Bharti VK, Srivastava RS, Kumar H, et al. Effects of melatonin and epiphyseal proteins on fluoride-induced adverse changes in antioxidant status of heart, liver, and kidney of rats. Adv Pharmacol Sci. 2014;2014:532969.

6. Song GH, Gao JP, Wang CF, et al. Sodium fluoride induces apoptosis in the kidney of rats through caspase-mediated pathways and DNA damage. J Physiol Biochem. 2014; 70 (3):857-868.

7. Bonetti G, Carta M, Montagnana M, et al. Effectiveness of citrate buffer-fluoride mixture in Terumo tubes as an inhibitor of in vitro glycolysis. Biochem Med (Zagreb). 2016;26 (1):68-76

8. Choi AL, Sun G, Zhang Y, et al. Developmental fluoride neurotoxicity: a systematic review and meta-analysis. Environ Health Perspect. 2012;120(10):1362-1368.

9. Everett ET. Fluoride's effects on the formation of teeth and bones, and the influence of genetics. J Dent Res. 2011;90(5):552-560.

10. Zhang YL, Luo Q, Deng Q, et al. Genes associated with sodium fluoride-induced human osteoblast apoptosis. Int J Clin Exp Med. 2015;8(8):13171-13178.

11. He LF, Chen JG. DNA damage, apoptosis and cell cycle changes induced by fluoride in rat oral mucosal cells and hepatocytes. World J Gastroenterol. 2006;12(7):1144-1148.

12. Tabuchi Y, Yunoki T, Hoshi N, et al. Genes and gene networks involved in sodium fluoride-elicited cell death accompanying endoplasmic reticulum stress in oral epithelial cells. Int J Mol Sci. 2014;15 (5):8959-8978.

13. Bagmut I, Kolisnyk I, Titkova A. The pathochemical mechanisms of action of sodium flouride on the body. LAP Lambert Academic Publishing, 2017: 43 p.

14. Meng H, Zhang T, Liu W, et al. Sodium fluoride induces apoptosis through the downregulation of hypoxia-inducible factor- $1 \alpha$ in primary cultured rat chondrocytes. Int J Mol Med. 2014;33(2):351-358.

15. Nguyen Ngoc TD, Son YO, Lim SS, et al. Sodium fluoride induces apoptosis in mouse embryonic stem cells through 
ROS-dependent and caspase- and JNK-mediated pathways. Toxicol Appl Pharmacol. 2012;259(3):329-337.

16. Picco DC, Delbem AC, Sassaki KT, et al. The effect of chronic treatment with fluoride on salivary activity, tooth, and bone in spontaneously hypertensive rats (SHR). Naunyn Schmiedebergs Arch Pharmacol. 2014;387(4):321-328.

17. Bagmut I, Kolisnyk I, Titkova A, Petrenko T, Filipchenko S. Content of catecholamines in blood serum of rats under fluoride intoxication. Georgian Medical News. 2018;7-8(280-281):125-129.

18. Sarkar C, Pal S. Ameliorative effect of resveratrol against fluoride induced alteration of thyroid function in male Wistar rats. Biol Trace Elem Res. 2014;162(1-3):278-287.

19. Abdel-Gawad FA, Ashmawy MH, Zaki SM, et al. Lung damage after long-term exposure of adult rats to sodium fluoride. Arch Med Sci. 2014;10(5):1035- 1040.

20. Shetty KP, Satish SV, Gouda V, et al. Comparative evalua tion and effect of organic and inorganic fluoride dentifrices on enamel microhardness: An in vitro study. J Int Soc Prev Community Dent. 2016;6(2):130-133.

21. Bhawal UK, Lee HJ, Arikawa K, et al. Micromolar sodium fluoride mediates antiosteoclastogenesis in Porphyromonas gingivalis-induced alveolar bone loss. Int J Oral Sci. 2015;7(4):242-249

22. Bagmut I, Kolisnyk I, Titkova A, Babiy L, Filipchenko S. The antioxidant system enzymes' activity in rats' brain,intoxicated with sodium fluoride in subtoxic doses. Arch Balk Med Union. 2018;53(4):506-511.
23. Susik MS, Prakash PA, Rao TM. Effects of different concentrations of fluoride in oral mucosal cells in albino rats. J Clin Diagn Res. 2015;9(12):ZF01-ZF04.

24. Jothiramajayam M, Sinha S, Ghosh M, et al. Sodium fluoride promotes apoptosis by generation of reactive oxygen species in human lymphocytes. J Toxicol Environ Health A. 2014;77(21):1269-1280.

25. Tressaund A, Haufe G. Fluorine and Health. Elsevier, Hungary. 2008. -805 p.

26. Wei R, Luo G, Sun Z, et al. Chronic fluoride exposure-induced testicular toxicity is associated with inflammatory response in mice. Chemosphere. 2016;153:419-425.

27. Alhawij H, Lippert F, Martinez-Mier EA. Relative fluoride response of caries lesions created in fluorotic and sound teeth studied under mineralizing conditions. J Dent. 2015;43(1):103-109.

28. Yan X, Yang X, Hao X, et al. Sodium fluoride induces apoptosis in $\mathrm{H} 9 \mathrm{c} 2$ cardiomyocytes by altering mitochondrial membrane potential and intracellular ROS level. Biol Trace Elem Res. 2015;166(2):210-215.

29. Fina BL, Lombarte M, Rigalli JP, et al. Fluoride increases superoxide production and impairs the respiratory chain in ROS 17/2.8 osteoblastic cells. PLoS One. 2014;9: Art. e100768.

30. Lee J, Han YE, Favorov O, et al. Fluoride induces a volume reduction in CA1 hippocampal slices via MAP kinase pathway through volume regulated anion channels. Exp Neurobiol. 2016;25(2):72-78. 